\title{
Erythropoietin receptor mutation-a rush of blood to the head?
}

\author{
Andreas Holbro • Radek Skoda • Pontus Lundberg • \\ Jakob Passweg • Andreas Buser • Thomas Lehmann
}

Received: 29 January 2015 / Accepted: 23 February 2015 / Published online: 14 March 2015

(C) Springer-Verlag Berlin Heidelberg 2015

\begin{abstract}
Abbreviations
EPO Erythropoietin

VHL von Hippel-Lindau

EPO-R Erythropoietin receptor
\end{abstract}

\section{Dear Editor,}

A 25 -year-old otherwise healthy patient was referred by his family physician for investigation of polyglobulia. His hemoglobin was $210 \mathrm{~g} / \mathrm{L}$ (reference value 140 $180 \mathrm{~g} / \mathrm{L}$ ) with a hematocrit of $60 \%$ (reference 38 $52 \%$ ). The family history was remarkable, as four relatives, including the patient's mother, were affected by polyglobulia (Fig. 1). Clinical investigation was inconspicuous; in particular, no splenomegaly was noticed. After a total of six phlebotomies performed by his family physician within 8 months, the patient's hemoglobin and hematocrit were $192 \mathrm{~g} / \mathrm{L}$ and $56 \%$, respectively. All other blood values and the peripheral blood smear were otherwise unremarkable. A relative polyglobulia could be excluded by history and clinical examination. As the patient's family history was indicative, we

A. Holbro · J. Passweg $\cdot$ A. Buser

Department of Hematology, University Hospital Basel,

Basel, Switzerland

A. Holbro · A. Buser

Blood Transfusion Centre, Swiss Red Cross, Basel, Switzerland

R. Skoda $\cdot$ P. Lundberg $\cdot$ T. Lehmann

Experimental Hematology, Department of Biomedicine, University

Hospital Basel, Basel, Switzerland

T. Lehmann $(\bowtie)$

Department of Hematology, Center for Laboratory Medicine,

Frohbergstrasse 3, 9001 St. Gallen, Switzerland

e-mail: thomas.lehmann@zlmsg.ch supposed a hereditary hemoglobinopathy with increased oxygen affinity. However, a high-performance liquid chromatography was unremarkable and the partial pressure of oxygen at which the hemoglobin is $50 \%$ saturated (P50) was normal. Other obvious secondary causes of polyglobulia were also excluded. Erythropoietin (EPO) level was suppressed $(<0.6 \mathrm{IU} / \mathrm{L}$, normal range 4.3-29.0 IU/L). To exclude a myeloproliferative neoplasia (polycythemia vera; PV), we performed a bone marrow aspirate and biopsy, stem cell cultures, conventional cytogenetics, and a mutation analysis (JAK2 V617F exon 14 and JAK2 exon 12 mutation including pyrosequencing). All these investigations turned out to be normal, thus definitively ruling out PV. Eventually, we performed a sequence analysis of the erythropoietin receptor (EPO-R) gene, which showed a mutation in exon 8 (6002delG). This nonsense mutation leads to a stop codon and results thus in a truncated cytoplasmic domain of the EPO-R protein.

Polyglobulia is a common finding in internal medicine and hematology patients. This can be either relative in case of a decreased plasma volume (i.e., dehydration, diuretics) or true. The latter can be further divided in primary (i.e., hematopoietic stem cell related) or secondary polyglobulia. Additionally, polyglobulia can be classified as congenital or acquired. In patients presenting with true polyglobulia, EPO level should be demanded after a careful history and clinical examination. This allows the discrimination of patients in two major groups: the first with low EPO level, which can then be investigated for primary causes of erythrocytosis including polycythemia vera, and the second group with normal or even high EPO level, where secondary causes (hemoglobinopathies, cardiopulmonary diseases, and malignancies with paraneoplastic EPO production) have to be explored (Fig. 2). 


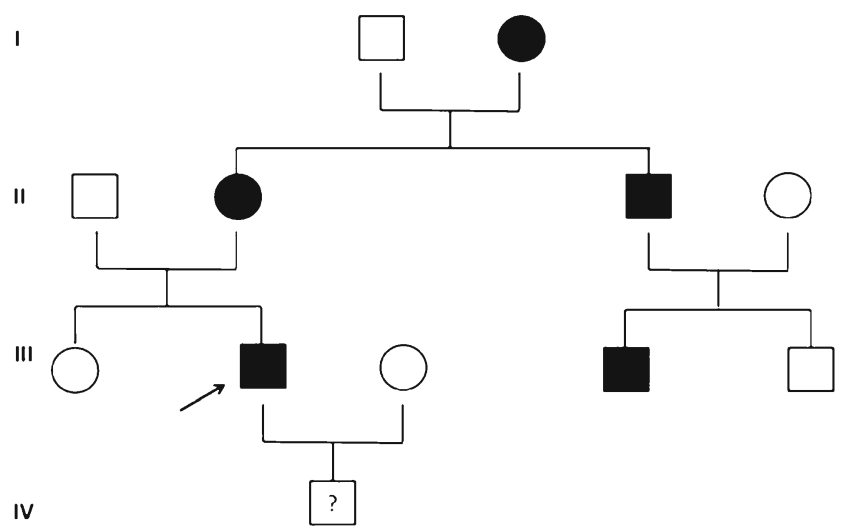

Fig. 1 Pedigree of our patient

Primary congenital erythrocytosis (CE) represents an uncommon clinical entity and is associated with low erythropoietin levels and results from mutations in the EPO-R gene. CE can be inherited either in an autosomal dominant or recessive mode, depending on the affected gene. Interestingly, in a recent case series of 70 $\mathrm{CE}$ patients, a causative mutation was found in only $36 \%$ of the patients, despite sequencing all the genes described to cause $\mathrm{CE}[1,2]$. Overproduction of red blood cells (RBC) leads to elevated hemoglobin concentration and hematocrit levels due to a dysregulated RBC production. Congenital polycythemia can also be secondary to inherited conditions that lead to increased EPO levels. Examples include hemoglobins with high affinity for oxygen and congenital cyanotic heart or lung disease [3, 4]. PV is an acquired hematologic disorder that belongs to the myeloproliferative neoplasias and is characterized by increased hemoglobin and the presence of the JAK2 V617F mutation in more than $95 \%$ of the patients [5]. Secondary acquired polyglobulia is often related to heart or lung diseases (e.g., severe chronic obstructive pulmonary disease). Interestingly, a suppressed EPO level even after several phlebotomies excludes secondary erythrocytosis but cannot discriminate between PV and EPO-R mutations [6].

There is no consensus on the therapy of CE. The treatment approach should be individualized taking into account symptoms, overt cardiovascular disease, age, additional risk factors for thromboembolic events including the well-known cardiovascular risk factors, and other possible blood count abnormalities.

We treated our patient with low-dose aspirin and phlebotomies, aiming a hematocrit of less than $55 \%$, in order to prevent ischemic complications. This approach was chosen in analogy to the current treatment standards in PV, although the target hematocrit in our patient is higher.
Fig. 2 Differential diagnostic algorithm of polyglobulia.

*Hepatoma, hepatocellular carcinoma, nephroblastoma, renal cell carcinoma, hemangioblastoma, endocrine tumours.

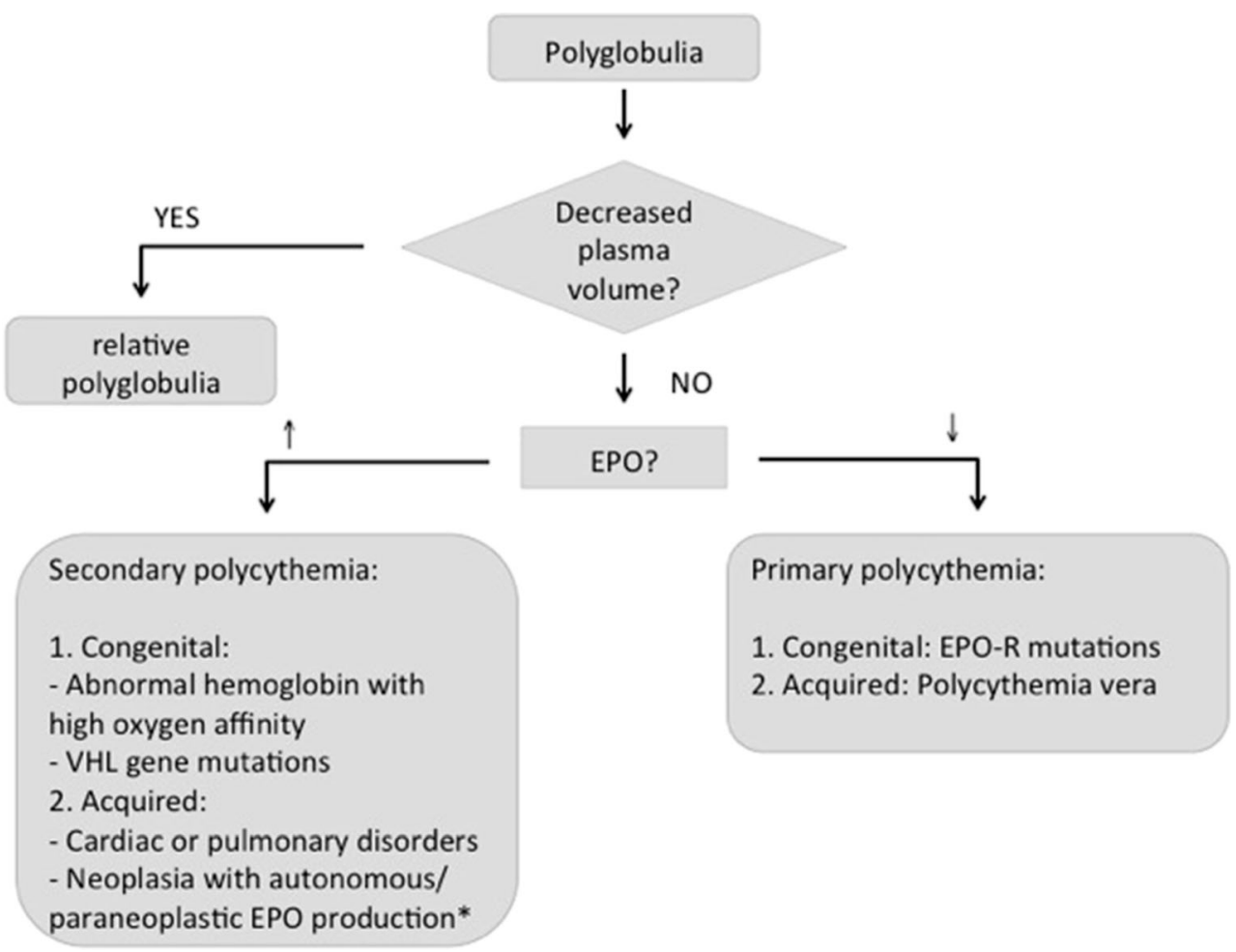




\section{Conflict of interest}

The authors declare that they have no conflict of interest.

\section{References}

1. Bento C, Almeida H, Maia TM, Relvas L, Oliveira AC, Rossi C, Girodon F, Fernandez-Lago C, Aguado-Diaz A, Fraga C, Costa RM, Araujo AL, Silva J, Vitoria H, Miguel N, Silveira MP, Martin-Nunez G, Ribeiro ML (2013) Molecular study of congenital erythrocytosis in 70 unrelated patients revealed a potential causal mutation in less than half of the cases (Where is/are the missing gene(s)?). Eur J Haematol 91(4):361-368. doi:10.1111/ejh.12170

2. de la Chapelle A, Traskelin AL, Juvonen E (1993) Truncated erythropoietin receptor causes dominantly inherited benign human erythrocytosis. Proc Natl Acad Sci U S A 90(10):4495-4499

3. Gordeuk VR, Stockton DW, Prchal JT (2005) Congenital polycythemias/erythrocytoses. Haematologica 90(1):109-116
4. Consortium ECE, Bento C, Percy MJ, Gardie B, Maia TM, van Wijk R, Perrotta S, Della Ragione F, Almeida H, Rossi C, Girodon F, Astrom M, Neumann D, Schnittger S, Landin B, Minkov M, Randi ML, Richard S, Casadevall N, Vainchenker W, Rives S, Hermouet S, Ribeiro ML, McMullin MF, Cario H, Consortium ECE, Chauveau A, Gimenez-Roqueplo AP, Bressac-de-Paillerets B, Altindirek D, Lorenzo F, Lambert F, Dan H, Gad-Lapiteau S, Catarina Oliveira A, Rossi C, Fraga C, Taradin G, Martin-Nunez G, Vitoria H, Diaz Aguado H, Palmblad J, Vidan J, Relvas L, Ribeiro ML, Luigi Larocca M, Luigia Randi M, Pedro Silveira M, Percy M, Gross M, Marques da Costa R, Beshara S, Ben-Ami T, Ugo V (2014) Genetic basis of congenital erythrocytosis: mutation update and online databases. Hum Mutat 35(1):15-26. doi:10.1002/humu.22448

5. Vardiman JW, Thiele J, Arber DA, Brunning RD, Borowitz MJ, Porwit A, Harris NL, Le Beau MM, Hellstrom-Lindberg E, Tefferi A, Bloomfield CD (2009) The 2008 revision of the World Health Organization (WHO) classification of myeloid neoplasms and acute leukemia: rationale and important changes. Blood 114(5):937-951. doi:10.1182/blood-2009-03-209262

6. Mossuz P, Girodon F, Donnard M, Latger-Cannard V, Dobo I, Boiret N, Lecron JC, Binquet C, Barro C, Hermouet S, Praloran V (2004) Diagnostic value of serum erythropoietin level in patients with absolute erythrocytosis. Haematologica 89(10):1194-1198 